\title{
Age and sex influence in canineRed Cell Distribution Width (RDW-CV and RDW-SD) values
}

\section{Valores dos índicesde anisocitose (RDW-CV e RDW-SD) em cães: influência da idade e do sexo}

\author{
Aline Moreira de Souza, ${ }^{*}$ Mariana Barbosa Camargo, ${ }^{*}$ Daniela TendlerLeibelBacellar, ${ }^{* *}$ \\ Sabrina DestriEmmerick Campos, ${ }^{*}$ Rodolpho AlmeidaTorres Filho, ${ }^{* * *}$ Nayro Xavier de Alencar, ${ }^{*}$ \\ Marcia de Souza Xavier, ${ }^{*}$ Daniel de Barros Macieira, ${ }^{*}$ Nádia Regina Pereira Almosny*
}

\begin{abstract}
Resumo
O objetivo do presente estudo foi verificar a influência da idade e do sexo nos valores dos índices RDW-CV (Amplitude de distribuição de hemácias como coeficiente de variação) e RDW-SD (Amplitude de distribuição de hemácias como desvio-padrão) em hemogramas de cães clinicamente sadios. Foram analisados os resultados de 332 hemogramas de cães, sendo 136 machos e 196 fêmeas. Os animais foram divididos em três grupos de acordo com a idade: animais até um ano $(n=42)$, animais entre um e nove anos $(n=104)$ e animais acima de 9 anos $(n=186)$. Todos os exames foram processados no Contador Hematológico Automatizado Veterinário Sysmex® - Poch 100 iV, no período de setembro de 2009 a setembro de 2010 e os resultados foram confirmados por análise microscópica dos esfregaçossanguíneos. Os valores médios e os desvios-padrão para RDW-CV (\%) foram de 10,74 $\pm 1,53$, próximos aos valores citados na literatura. Para RDW-SD (fL),os valores obtidos foram de 32,01 $\pm 7,56$. Entretanto, nos trabalhos já realizados, não foram encontrados valores de referência para este índice em cães. Não houve diferença significativa nos valores encontrados para estes índices entre machos e fêmeas ou entre as diferentes faixas etárias, podendo ser utilizados como referência para ambos os sexos e todas as idades.
\end{abstract}

Palavras-chave: anisocitose, cão, hematologia.

\begin{abstract}
The aim of this study was to verify age and sex influence on RDW-CV (Red blood cell distribution width measured by Variation Coefficient)and RDW-SD (Red blood cell distribution width measured by Standard Deviation) values in healthy dogs' blood tests. Were analyzed the results of blood tests of 332 dogs( 136 males and 186 females). These results were further divided into three groups according to age: animals up to one year $(n=42)$, with one to nine years $(n=104)$ and over nine years $(n=186)$.All Complete blood count (CBC) tests were processed in the Automated Veterinary hematology counter Sysmex $®$ - Poch 100 iV during the period September 2009 to September 2010 and the results were confirmed by microscopic analyses of blood films. The mean values and standard deviations for RDW-CV (\%) were $10.74 \pm 1.53$, similar to values cited in literature. For RDW-SD (fL) the obtained values were $32.01 \pm 7.56$. However, there are no reference values for this index in literature for dogs. There was no significant difference in values for these indices between males and females or different age groups. These data can be used as reference for both genders within all ages.
\end{abstract}

Keywords: anisocytosis, dog, hematology.

\section{Introduction}

Complete blood count $(\mathrm{CBC})$ is an exam constantly requested by veterinary clinicians to evaluate the health status of the animals, therefore because it supplies quantitative and qualitative information on all blood cells, searching for abnormalities or a response to disease(Rizzi et al, 2010). Recently an increase in the use of automated veterinary hematology counters has been experienced. As a result, indices that were not calculated in manually performed $\mathrm{CBCs}$ are now being introduced in the results of this test, as the RDW-CV and, recently, the RDW-SD, known as indices of anisocytosis, as well as parameters that evaluate platelets morphology, like mean platelet volume (MPV) and platelet distribution width (PDW)(Balarin et al, 2001; Temizel et al, 2011).

\footnotetext{
* Departamento de Patologia e Clínica Veterinária - Faculdade de Veterinária - Universidade Federal Fluminense. Rua Vital BrazilFilho, 64. Niterói, RJ. CEP 24230-340.

** Faculdade de Medicina Veterinária, Universidade Castelo Branco, Rio de Janeiro, RJ

*** Departamento de Zootecnia - Faculdade de Veterinária - Universidade Federal Fluminense.
}

Autor para correspondência: Aline Moreira de Souza. E-mail: alinems@id.uff.br. 
Automated cell counters show the erythrocyte volume distribution of $95 \%$ of blood sample, in histogram form, and determine its coefficient of variation, being called RDW-CV or red cell distribution width. This index is calculated and relatively expressed (percentage) and correlates to the mean corpuscular volume (MCV), indicating the average size of erythrocytes(Weiser et al, 1983; Roberts e ElBadawi, 1983;Perret et al, 2001; Balarin et al, 2006; Zhu et al, 2010). The RDW-SD is the standard deviation of the erythrocyte distribution curve, expressed in fentoliter (absolute value), same unit of the MCV. This index is a direct measure of the erythrocyte distribution curve and more accurately reflects variations in the size of these cells (Brollo e Tavares, 2010)

Red cell distribution width is described as more accurate, precocious and less subjective when compared with microscopic observations of anisocytosis, which many times can be misidentified (Balarin et al, 2006; Zhu et al, 2010; Simelet al, 1988;Neigeret al, 2002; Žvorc et al, 2010). These laboratory parameters are frequently overlooked in veterinary clinical practice (Ferreira et al, 2009; Žvorc et al, 2010).With reticulocyte count, MCV is the most widely used parameter for anemia classification and bone marrow response. However, a great number of erythrocytes with modified volume is necessary to modify this index. On the other hand, a small variation of the size of these cells can modify the RDW (Simelet al, 1988;Neigeret al, 2002; Žvorcet al, 2010).

Regardless of reticulocyte count and cytological examination of bone marrow, regeneration of anemia can be evaluated by use of RBC and platelet indices (Flaiban e Balarin, 2004). In human medicine, RDW-CV and RDW-SD are widely used, mainly for evaluation of bone marrow response in anemic patients, assisting the clinician to introduce a better therapy(Perret et al, 2001). In veterinary medicine there are few studies on the relevance of this index in the interpretation of animals CBC (Flaiban e Balarin, 2004; Ferreira et al, 2009; Žvorc et al, 2010). In dogs, RDW and MCV are important tools to classify anemias (Neigeret al, 2002; Ferreira et al, 2009; Žvorc et al, 2010; Temizel et al, 2011).Increased RDW in dogs and human is typically elevated in regenerative anemias (increased red cell destruction or loose, such as haemolysis or hemorrhagic disorders) or in conditions of ineffective red cell production (such as iron, B12 or folate deficiency, and haemoglobinopathies), or following blood transfusion(Žvorc et al, 2010; Temizel et al, 2011). Uniform microcytosis or macrocytosis is not easily recognized in peripheral smears, but can be indicated by the mean cell volume (MCV) (Žvorc et al, 2010).

Different hematological counters yield different values for RDW. Thus, the literature reference values are not standardized for animals, and some indices had not been published (Balarin et al, 2006; Neiger et al, 2002; Žvorc et al, 2010).

The present study aimed to verify the influence of age and sex in RDW-CV (Red Blood Cell Distribution Width measured by Variation Coefficient) and RDW-SD (the same measured by Standard Deviation) values of clinically healthy dogs using the Automated Veterinary Hematology counter Sysmex ${ }^{\circledR}$ - Poch $100 \mathrm{IV}$.

\section{Materials and methods}

The results of 332 dogs' CBCs, processed in automated veterinary hematology counter Sysmex $®$ - Poch 100 IV DIFF were analyzed from September 2009 to September 2010. The tests were performed in the Clinical Pathology Laboratory of the Veterinary Teaching Hospital Prof. FirminoMarsicoFilhoatUniversidade Federal Fluminense - HUVET-UFF. Clinically healthy animals meeting all CBCs parameters reference values(Rizzi et al, 2010) and with no morphological changes in blood cells microscopic evaluation were used in this study.Samples were processed following cephalic or jugular venipuncture. The blood smears were stained by diff quick staining (Panóticorápido®) and analyzed using $100 \times$ objective to confirm the results of $\mathrm{CBC}$, to perform leukocyte differentiation and search for abnormalities. In order to check the equipment results, blood control samples are analyzed daily, besides the participation in an external quality assessment program. The results of CBCs were split between males $(n=136)$ and females $(n=196)$ for detecting differences between sexes. These results were further divided into three groups according to age: animals up to one year $(n=42)$, with one to nine years $(n=104)$ and over nine years $(n=186)$ for detecting differences between different age groups. The effect of age and sex was evaluated using variance analysis (ANOVA), and expressed as Mean \pm SD. Pearson's correlation coefficient was used to test association between variables. Results were considered significant when $p<0.05$.

This study was approved by the Ethics Committee on Animal Research of the Universidade Federal Fluminense (CEUA-UFF), with number 00157/09.

\section{Results and discussion}

The average values and standard deviations of anisocytosis indices (RDW-CV and RDW-SD) and coefficient of variation in healthy dogs, processed in Automated Veterinary Hematology counter Sysmex® - Poch 100IV are shown in Table 1.

Table 1: Mean values and standard deviations (SD) and coefficient of variation of RDW-CV and RDW-SD values in blood samples of healthy dogs, processed in Automated Veterinary Hematology Counter SysmexPoch $100 \mathrm{iV}$

\begin{tabular}{lll}
\hline & Mean & CV \\
\hline Variable & Mean \pm SD & CV \\
RDW-CV $(\%)$ & $10.67892 \pm 1.73435$ & $16.24 \%$ \\
RDW-SD(fL) & $32.0186 \pm 7.56095$ & $23.61 \%$ \\
\hline
\end{tabular}

Pearson's coefficient value was 0.11839 , significant in $5 \%$ probability. This indicates slow association between RDW-CV and RDW-SD values.

The average values and standard deviations of anisocytosis indices (RDW-CV and RDW-SD) in healthy dogs, males and females, of different ages, processed in Automated Veterinary Hematology counter Sysmex® - Poch 100IV are shown in Tables 2 and 3.

RDW-CV and RDW-SD values found in healthy dogs were not different when considering animal gender $(p>0.05)$, confirming other findings(Flaiban e Balarin, 2004; Ferreira et al, 2009). Likewise, the values found in the different age didnot present significant difference $(p>0.05)$. Thus, a general average was 
Table 2: Mean values and standard deviations (SD) of RDW$\mathrm{CV}$ and RDW-SD values in blood samples of healthy dogs, males and females, processed in Automated Veterinary Hematology Counter SysmexPoch 100 iV

\begin{tabular}{lll}
\hline & Male $(\mathrm{n}=136)$ & Female $(\mathrm{n}=196)$ \\
\hline Variable & Mean \pm SD & Mean \pm SD \\
RDW-CV $(\%)$ & $10.70 \pm 1.38$ & $10.77 \pm 1.62$ \\
RDW-SD $(\mathrm{fL})$ & $32.05 \pm 7.46$ & $31.99 \pm 7.64$ \\
\hline
\end{tabular}

Table 3: Mean values and standard deviations (SD) of RDWCV and RDW-SD values in blood samples of healthy dogs of different ages, processed in Automated Veterinary Hematology Counter SysmexPoch 100 iV

\begin{tabular}{lccc}
\hline & $\begin{array}{c}\text { Up to 1 year } \\
(\mathrm{n}=42)\end{array}$ & $\begin{array}{c}\text { Between 1 and } \\
9 \text { years }(\mathrm{n}=186)\end{array}$ & $\begin{array}{c}\text { Over 9 years } \\
(\mathrm{n}=104)\end{array}$ \\
\hline Variable & Mean $\pm \mathrm{SD}$ & Mean $\pm \mathrm{SD}$ & Mean $\pm \mathrm{SD}$ \\
RDW-CV $(\%)$ & $10.86 \pm 1.76$ & $10.59 \pm 1.44$ & $10.96 \pm 1.56$ \\
RDW-SD $(\mathrm{fL})$ & $31.01 \pm 9.42$ & $32.47 \pm 6.18$ & $31.61 \pm 8.87$ \\
\hline
\end{tabular}

achieved, using the results of all dogs $(n=332)$, regardless of sex or age with the objective to determine the values of these parameters in healthful animals.

The values found for RDW-CV (\%) in healthy dogs had been of $10.74 \pm 1.53$, lower thansome studies (Ferreira et al, 2009;
Žvorc et al, 2010; Temizel et al, 2011). The methodology used for the enumeration and differentiation of cells in counter Sysmex ${ }^{\circledR}$ - Poch 100 IV DIFF, used in present study, is based on passage of individual blood cells through an aperture between two electrodes resulting in a change in electrical resistance across the aperture in function of the volume of the cells, known as impedance methods (Deprezet al, 2009). However, others used a different equipment to run CBCs, the CELL-DYN 3500 (Abbott), a combined impedance light-scatter analyzer that use flow cytometry to identify blood cells in veterinary samples, fact which may have contributed for the discrepancy of the values (Deprezet al, 2009; Ferreira et al, 2009; Žvorc et al, 2010; Temizel et al, 2011).

On the other hand, similar results were described for healthy dogs in two studies that used a laser-based hematology system, the ADVIA 120 (Bayer) (Tvedten, 1999; Moritz et al, 2004)

Moreover, other conditions, such as differences between breed, collection procedures, animals household, subclinical illness, among others, could also have caused the variation between the joined values (Rizzi et al, 2010; Temizel et al, 2011).

For what concerns RDW-SD results obtained in this study were $32.01 \pm 7.56$ (fL), however there are no reference described for this parameter in dogs.

\section{Conclusions}

The average values found for RDW-CV and RDW-SD in blood samples processed in Automated Veterinary Hematology counter Sysmex® Poch 100 IV, could be used as reference in healthy dogs, regardless age or sex, in related hematologic counters.

\section{Acknowledgment}

To CNPq, FAPERJ and Proppi/UFF for financial support and scholarship and to Controllab ${ }^{\circledR}$ for quality control.

\section{References}

BALARIN, M.R.S.; FONTEQUE, J.H.; SOUZA, C.; SAITO, M.E.; KOHAYAGAWA, A.; LOPES, R.S. Valores da amplitude de distribuição do tamanho dos eritrócitos (RDW - Red Cell Distribuition Wicth) em equinos da raça Puro Sangue Inglês (PSI) de ambos os sexos de 12 a 24 meses de idade. Semina: CiAgr., v. 22, p.135-137, 2001.

BALARIN, M.R.S.; LOPES, R.S.; KOHAYAGAWA, A.; LAPOSY, C.B.; FONTEQUE, J.H. Valores da amplitude da distribuição do tamanho dos eritrócitos (RDW) em equinos Puro Sangue Inlgês (PSI) submetidos a exercícios de diferentes intensidades. Braz. J. Vet. Res. Anim. Sci., v.43, p.637-641, 2006.

BROLLO, C.; TAVARES, R.G. Avaliação Comparativa dos Parâmetros Hematológicos RDW-CV e RDW-SD. NewsLab, v.103, p.164-168, 2010.

DEPREZ, P.; BAUWENS, C.; VAN SCHANDEVIJL, K.; LEFĖRE, L.; NOLLET, H.; DE CLERCQ, D.; VAN LOON, G. Evaluation of the pocH-100iV DIFF hematology analyzer for use in horses and cattle. VlaamsDiergeneeskundigTijdschrift, v.78, p.105-109, 2009.

FERREIRA, G.S.; MASSON, G.C.I.H.; COSTA, E.D.C.P. Standardization of Red Blood Cell Distribution Width (RDW) Values in Dogs From Northern Region of Brazil.World Small Animal VeterinaryCongress (WSAVA). São Paulo; 2009. Disponível em: www.vin.com/proceedings, acesso em 20 setembro 2010.
FLAIBAN, K.K.M.C.; BALARIN, M.R.S. Estudo comparativo entre a amplitude de variação dos eritrócitos (RDW - Red Blood Cell Distribution Width) e o Volume Globular (VG), Volume Globular Médio (VGM) e a presença de anisocitose em extensão sangüínea em cães.Semina: Ci Agr., v. 25, p. 125-130, 2004.

MORITZ, A.; FICKENSCHER, Y.; MEYER, K.; FAILING, K.; WEISS, D.J. Canine and feline hematology reference values for the ADVIA 120 hematology system. Vet Clin Pathol, v.33, p.32-38, 2004.

NEIGER, R.; HADLEY, J.; PFEIFFER, D.U. Differentiation of dogs with regenerative and non-regenerative anaemia on the basis of their red cell distribution width and mean corpuscular volume. Vet Rec., v. 6, p.431-434, 2002.

PERRET, D.; TRUMEL, C.; DIQUELOU, A.; DOSSIN, O.; GULEFI, J.F. L'indice de distribution des globuler rouges (IDR) chez le chien. Analyse de 1400 cas. Revue Méd. Vét, v.152, p.549-554, 2001.

RIZZI, T.E.; MEINKOTH, J.H.; CLINKENBEARD, K.D. Normal Hematology of the Dog. In: WEISS DJ, WARDROPJK. Schalm's Veterinary Hematology. $6^{\text {th }}$ ed. Wiley-Blackwell, 2010, p. 799-810.

ROBERTS, G.T.; EL BADAWI, S.B. Red cell distribution width index in some hematologic diseases.Am J ClinPathol, v.83, p.226236, 1983

SIMEL, D.L.; DeLONG, E.R.; FEUSSNER, J.R.; WEINBERG, J.B.; CRAWFORD, J. Erythrocyte Anisocytosis: Visual Inspection of Blood Films vs Automated Analysis of Red Blood Cell Distribuition Width. Arch Intern Med., v.148, p.822-824, 1988. 
TEMIZEL, E. M.; CIHAN, H.; YILMAZ, Z.; AYTUG, N. Evaluation of erythrocyte and platelet indices in canine visceral leishmaniasis. Ankara Üniv Vet FakDerg,v. 58, p.185-188, 2011.

TVEDTEN, H. General laboratory concepts. In: WILLARD, M.D.; TVEDTEN, H.; TURNWALD, G.H. (Eds.) Small Animal Clinical Diagnosis by LaboratoryMethods. 4th ed. Philadelphia, PA: Saunders, 1999, p.1-10.

WEISER, G.; KOHN, C.; VACHON, A. Erythrocyte volume distribution analysis and hematologic changes in two horses with immune-mediated hemolytic anemia.Vet.Pathol.,v. 20, p.424-433, 1983.
ZHU, A.; KANESHIRO, M.; KAUNITZ, J.D. Evaluation and Treatment of Iron Deficiency Anemia:A Gastroenterological Perspective. Dig.Dis. Sci,v. 55, p. 548-559, 2010.

ŽVORC, Z.; RAFAJ, R.B.; KULEŠ, J.; MRLJAK, V. Erythrocyte and platelet indices in babesiosis of dogs. Vet. Archiv, v. 80, p. 259-267, 2010. 